\title{
Two Eras of Hungarian Constitutionalism: from the Rule of Law to rule by law
}

Nóra Chronowski (Hungarian Academy of Sciences, Institute of Legal Studies and ELTE, Faculty of Law) and Márton Varju (Hungarian Academy of Sciences, Institute of Legal Studies and University of Debrecen, Faculty of Law)

Address: Hungarian Academy of Sciences, Institute of Legal Studies, 1014, Budapest, Országház utca 30, Hungary

Email: varju.marton@tk.mta.hu

Phone: 0036203133976

\begin{abstract}
: $150-250$
Developments in Hungarian constitutional law after 2010 suggest that the era in Hungarian constitutionalism characterized by a commitment to the rule of law has been replaced by an era where the law is regarded as an instrument available to government to rule. Under the new Fundamental Law, which places alike the 1989 Constitution the rule of law at the centre of the constitutional order, the constraints which follow from the rule of law have been habitually overridden or ignored by the government acting in parliament. The Constitutional Court's attempts to continue the legacy of pre-2010 constitutionalism were reproached by the government delimiting the powers of the Court or overruling its decisions in formal amendments of the constitutional text. In the domain of economic regulation, the differences in how the Constitutional Court and European judicial fora assess the legal measures which have restructured entire markets give a clear indication that the rule of law in Hungary has lost its previous enjoyed position in the Hungarian constitutional order.
\end{abstract}

Keywords:

Hungary, constitutionalism, rule of law, limited government, constitutional court, backsliding

The manuscript has not been submitted and it is not under consideration elsewhere. 


\section{Two Eras of Hungarian Constitutionalism: from the Rule of Law to rule by law}

\section{Introduction}

In this article, we analyse whether in Hungary under the 2011 Fundamental Law ${ }^{1}$ the legacy of a strong rule of law principle and of its consistent enforcement by the Constitutional Court against arbitrary and abusive uses of public powers has now been abandoned for an order in which constitutionalism is habitually suspended while the government is at work. It contends, in particular, that despite the continued reliance on the rule of law in the Fundamental Law as the foundational principle of the Hungarian state, there have been a number of significant systemic developments which indicate that in the new constitutional order the ability of the government to rule by law enjoys priority over the idea that for government to be constitutional it must be constrained by law. The controversial practices followed in amending the constitutional text, the limitations imposed on the review powers of the Constitutional Court, and the evident subordination of the constitutional order as defended by the Constitutional Court to the political regime offer clear indications of this significant shift in Hungarian constitutionalism. The weakening of the rule of law in order to enable effective government rule by law is perhaps most conspicuous in the domain of economic regulation. The differences in how the Constitutional Court and European judicial fora assessed controversial legislation overhauling entire markets to the disadvantage of individuals give a depressing evidence of the interpretation accorded to the rule of law in post-2010 Hungary.

The article is structured in the following way. First, the position gained by the rule of law in Hungarian constitutionalism before 2010 is analysed. This is followed with an analysis of the changes introduced by the Fundamental Law as well as the controversial consequences of following from the new constitutional regime for the rule of law. Finally, we look at controversial developments in economic regulation in Hungary and the significant contrast between how their compliance with basic principles under the rule of law was assessed, on the one hand, by the Hungarian Constitutional Court and, on the other, by the European Court of Human Rights and the Court of Justice of the European Union.

\section{The rule of law in Hungarian constitutionalism before 2010}

The rule of law enjoyed a paramount position among the norms which constituted the constitutional order of post-1989 Hungary. It was modelled almost exclusively on the German Rechtsstaat concept. ${ }^{2}$ There is scholarly consensus ${ }^{3}$ that the incorporation of the substantive,

\footnotetext{
${ }^{1}$ The official English translation of the Fundamental Law (consolidated version after the Fourth Amendment) is available at http://www.mfa.gov.hu/NR/rdonlyres/8204FB28-BF22-481A-9426-

D2761D10EC7C/0/FUNDAMENTALLAWOFHUNGARYmostrecentversion01102013.pdf.

${ }^{2}$ As László Sólyom, the first president of the Constitutional Court outlined 'Even the traditional difference between the formal and the substantial concepts of the Rechtsstaat (...) was revived and had to be reinterpreted. (...) The Court made both the politicians and the population conscious of the secure protection constitutional rights (...) and aware of one of the most important characteristic of the rule of law: political intentions can only be implemented lawfully and within the framework of the Constitution - not vice versa, as before, when the law was conceived as
} 
structural and procedural components of the Rechtsstaat principle led to the anchoring in Hungarian constitutionalism of foundational ideas, such as the protection of fundamental rights, the separation of powers and limited government, the legality of public administration, legal certainty, the independence of the judiciary and the right of access to justice. The influence of the Rechtstaat principle also meant that in Hungary the written constitution enjoys the highest rank in the hierarchy of legal norms superseding other pieces of legislation, which primacy is manifested primarily through the process of constitutional review exercised by the Constitutional Court. The jurisprudence developed by the Constitutional Court in a long chain of constitutional review cases emphasized primarily the formal dimensions of the rule of law, especially the principle of legal certainty, and left the substantive aspects of the principle somewhat underdeveloped. ${ }^{4}$

The prominence of the rule of law among the principles of the constitution, which was matched only by the human dignity principle, and the emphasis on its formal dimensions were thought to provide an essential guarantee for the successful completion of the post-1989 transition process. ${ }^{5}$ The rule of law offered that formal guarantee which was able to establish a boundary between the constitutional arrangements which had been in place before the regime change and the new constitutional order where public powers are subjected to genuine legal constraints. The position held on the rule of law by the Constitutional Court, the central architect of the novel constitutional order and a key actor in the process of political and legal transition, was simple, but effective: "the rule of law cannot be achieved against the rule of law". ${ }^{6}$ This meant foremost that the Court systematically enforced the principle of legal certainty and applied the rule of law, which it aimed to interpret and develop as a neutral concept, ${ }^{7}$ as the fundamental benchmark of its constitutional control powers. ${ }^{8}$ It was interpreted as having a normative content independent from concrete constitutional provision the violation of which could give rise to protection before the Constitutional Court. The rule of law was also available to support as their conceptual basis more specific constitutional norms, and it provided a philosophical umbrella for the entire constitutional order, the individual norms of which were in turn available to give effect in individual instances to the rule of law as a general principle.

In the jurisprudence of the Constitutional Court under the 1989 Constitution, ${ }^{9}$ the rule of law emerged as a self-standing normative principle, and it was used to provide the basis of other, more specific constitutional norms, such as legal certainty and the separation of powers.

2.1 The rule of law as a self-standing constitutional norm

merely a political tool. (...) The Court, moreover, developed a moral explanation of its position. It introduced the paradoxical phrase "revolution under the rule of law".' Sólyom 2000, p. 38.

${ }^{3}$ Petrétei 2009, pp. 139-159.

${ }^{4}$ Győrfi and Jakab 2009, p. 174.

${ }^{5}$ Sólyom 2015, pp. 6-7.

${ }^{6}$ Decision $11 / 1992$ of the Constitutional Court.

${ }^{7}$ Tóth 2009, p. 147.

${ }^{8}$ For example, the Constitutional Court never paid much attention to the concept of democracy and to its relevance in constitutional interpretation, see, Minority Opinion of Judge Kiss in Decision 39/1999 of the Constitutional Court. ${ }^{9}$ Act 1949:XX on the Constitution of the Republic of Hungary as revised in 1989-90, in force until 31 December 2011. 
The 1989 Constitution declared that the Republic of Hungary is an independent, democratic state founded on the rule of law. ${ }^{10}$ The Constitutional Court stated that this definition introduced a new quality for state, law and the political system which is radically different from that experienced by citizens before the regime change, and added that the validity of this far-reaching statement is not affected by the fact that Hungary had only modified its 1949 constitution, instead of adopting a new constitutional document, in the process of democratic transition. ${ }^{11}$ The early decisions of the Court made it clear that the constitutional state based on rule of law (Rechtsstaat) was not only a fact which was recognized by the constitutional text upon its entry into force, but it was also a socio-political program for Hungary as a political community. ${ }^{12}$ Regarding the latter, the Court emphasized that the making and maintaining of the constitutional state is a permanent task and responsibility of state organs which need to adapt to the changing circumstances of constitutional reality. ${ }^{13}$ They are, thus, required as a constitutional obligation to take part in this process and make efforts to this end. ${ }^{14}$

The jurisprudence of the Constitutional Court made it clear that although the rule of law is interpreted to anchor and develop further, more specific constitutional norms, which in turn further define and detail its content, this alone does not define the entire normative content of the rule of law. The Court held that it regards the rule of law as an independent principle of the constitution, and that it is among its core tasks to develop that principle through interpretation. ${ }^{15}$ In the jurisprudence, the breach of the rule of law alone, or together with other constitutional norms could lead to declaring legislation unconstitutional. ${ }^{16}$ In the given circumstances, legal norms regulated in legal measures lower than the constitutional level could find themselves protected as constitutional norms having been incorporated into the rule of law principle. ${ }^{17}$ The self-standing principle rule of law was the most often litigated, interpreted and applied constitutional norm before the Constitutional Court, which was raised by the Court as an additional ground even when a more specific constitutional provision was available to solve the case. $^{18}$

\subsection{The rule of law, public powers and legal certainty}

In Hungarian constitutional law, where the development of the formal dimensions of the rule of law received particular emphasis so as to ensure the effective constitutional review of legislation adopted in a period of transition, legal certainty emerged as the primary, although not the only constitutional principle enforced under the rule of law. Legal certainty was interpreted to combine a number of principles affecting the functioning of government and the design and the application law. ${ }^{19}$ It covers the fundamental requirements that general rules (legislative

\footnotetext{
${ }^{10}$ Art. 2(1) of the 1989 Constitution.

${ }^{11}$ Decision $11 / 1992$ of the Constitutional Court.

12 ibid.

13 ibid.

14 ibid.

${ }^{15}$ Decision 9/1992 of the Constitutional Court.

${ }^{16}$ Decision 11/1992 of the Constitutional Court.

${ }^{17}$ Győrfi and Jakab 2009, p. 156.

18 ibid.

${ }^{19}$ Győrfi and Jakab 2009, p. 163.
} 
provisions) must be available to confine the use of public powers and that the use of public powers must be based on legal provisions. It also includes the requirement that law must be able to secure its own application and to ensure that it is complied with. As to matters of regulatory design, it requires that the content of legal provisions must be certain and predictable, and that the legal system must have a minimal effectiveness. ${ }^{20}$

The first of these requirements addresses the abuse and arbitrary uses of public powers. ${ }^{21}$ The second demands that public authorities must operate in institutional and operational frameworks established in law, and that they carry out their activities within transparent and predicable legal frameworks. ${ }^{22}$ Connected to these requirements, legal certainty is regarded to provide the basis of administrative legality - in the Hungarian terminology, the principle of the lawfulness of administrative decisions ${ }^{23}$, and holds that public authorities (and courts) must have a legal basis (a legally determined jurisdiction, or vires) for their actions. ${ }^{24}$ It demands specifically that administrative authorities proceed in predicable and fair procedures. ${ }^{25}$ In judicial procedures, legal certainty is expressed with the help of the specific constitutional provisions on fair trial rights, the double jeopardy rule, and on the prohibition on self-incrimination. In legislative procedures, legal certainty stands for the principle that valid legislation may only emerge from lawful processes ${ }^{26}$ the violation of which, although in limited circumstances, may lead to the Constitutional Court striking down legislation. ${ }^{27}$

The requirement that law should be able to secure its own application and to ensure that it is complied with is interpreted primarily as the obligation to publish legislation and make it accessible in the official journal of Hungary. ${ }^{28}$ The requirement is applied usually in the assessment of the use of soft law and other informal instruments of governance to prescribe a particular compulsory interpretation of legal provisions for public authorities. ${ }^{29}$ The prohibition on legislation having a retrospective effect, which was interpreted as an inevitable expression of liberty in a constitutional democracy, was developed under this limb of the legal certainty principle. ${ }^{30}$ In general, this requires that a legislative measure cannot establish obligations for individuals and declare conducts unlawful for the time period before its publication. ${ }^{31}$

Legal certainty also demands that legal provisions are clear and rational, and that their content is clearly and easily identifiable in the process of their application. ${ }^{32}$ The certainty and predictability of legislative content, which are necessary to ensure a 'minimal stability' of law, were interpreted as preconditions for the observance of the law by public authorities and

\footnotetext{
20 ibid.

${ }^{21}$ Decision 288//B/2002 of the Constitutional Court.

${ }^{22}$ Decision 56/1991 of the Constitutional Court.

${ }^{23}$ Decision $2 / 2000$ of the Constitutional Court.

${ }^{24}$ Decisions 317/E/1990 and 6/1999 of the Constitutional Court.

${ }^{25}$ Decisions $72 / 1995$ and 10/2001 of the Constitutional Court.

${ }^{26}$ Decision 9/1992 of the Constitutional Court.

${ }^{27}$ Decision 29/1997 of the Constitutional Court.

${ }^{28}$ Decisions 34/1994, 15/1999 and 47/2003 of the Constitutional Court.

${ }^{29}$ Decision $45 / 2001$ of the Constitutional Court.

${ }^{30}$ Decision 8/2005 of the Constitutional Court.

${ }^{31}$ Decision 28/1993 of the Constitutional Court. See also the nullum crimen, nulla poena sine lege principles.

${ }^{32}$ Decisions 35/1991, 11/1992, 26/1992, 21/2001 and 8/2003 of the Constitutional Court.
} 
individuals. ${ }^{33}$ Under these principles, the legislator, when amending legislation, is required, in particular, to allow sufficient time for the persons concerned to prepare for the application of the new legislative provisions. ${ }^{34}$ The sufficient time requirement refers to the time necessary to access the new legislative text, for public authorities and courts to prepare for the application of the new provisions, and for individuals to adapt to the new legal circumstances. ${ }^{35}$ In Hungarian constitutional law, legal certainty and predictability provided the basis for the protection of acquired rights and legitimate expectations of individuals, ${ }^{36}$ mainly in connection with the protection of social rights. ${ }^{37}$ The formal understanding of legal certainty also includes the general duty of the state to ensure that legal provisions are in fact applied, which is interpreted as the obligation to take every step necessary to ensure the effective operation of the legal system. ${ }^{38}$

\subsection{The rule of law and the separation of powers}

The separation of powers was not recognized explicitly in the 1989 Constitution as a constitutional principle. ${ }^{39}$ It was the jurisprudence of the Constitutional Court, based on the principle of the rule of law, which anchored in Hungarian constitutionalism the principle of the division and the separation of the different branches of public power. ${ }^{40}$ The core idea followed was that the power of public authorities cannot be unlimited, and that the exercise of those powers must subjected to the Constitution as a whole and also to individual constitutional provisions. Among the latter, the most important are the provisions regulating the institutional organization and operation of the Hungarian state, which were interpreted as available to give effect to the principle that the different branches of public powers are separated. ${ }^{41}$ The corresponding requirement following from the rule of law that powers under the constitution are neither unlimited, nor immune to potential limitations was given expression in the interpretative formula developed by the Constitutional Court that the different branches of powers necessarily set limitations to other branches of public powers. ${ }^{42}$

\section{Moving away from the rule of law towards rule by law after $\mathbf{2 0 1 0}$}

The new Fundamental Law accorded a position in Hungarian constitutionalism to the rule of law similar to that in the 1989 Constitution. Its Article B recognised the rule of law and democracy as the foundational principles of the Hungarian republic. Article $C$ contains the now self-standing principle of the separation of powers, which principle continues to be expressed in the detailed constitutional provisions on the organisation and the functioning of the state. Beyond the constitutional text, there are, however, a number of systemic developments which raise doubts as to the commitment of the new constitutional order, and of the political order which developed the

\footnotetext{
${ }^{33}$ Decision 32/1991 of the Constitutional Court.

${ }^{34}$ Decision 28/1992 of the Constitutional Court.

35 ibid.

${ }^{36}$ Decisions 11/1992, 62/1993 and 43/1995 of the Constitutional Court.

${ }^{37}$ Decisions 11/1991, 42/1997 and 16/2002 of the Constitutional Court.

${ }^{38}$ Győrfi and Jakab 2009, p. 192.

${ }^{39}$ Chronowski, Drinóczi and Petrétei 2011, pp. 307-308. Only the preamble of the now repealed act on the Constitutional Court took mention of the principle (Act 1989: XXXII, in force until 1 January 2012).

${ }^{40}$ Decision 30/1998 of the Constitutional Court.

${ }^{41}$ Decision 31/1990 of the Constitutional Court.

${ }^{42}$ Decision 28/1995 of the Constitutional Court.
} 
new constitutional framework, to sustaining and building upon the legacy of post-1989 Hungarian constitutionalism which had placed the rule of law at the heart of the functions performed by the constitution in the Hungarian political, economic and social order. ${ }^{43}$ These developments include the instability of the Fundamental Law which followed from its frequent, politically-driven modifications, the imposition of serious limitations on the constitutional review exercised by the Constitutional Court, and the open struggle between the Constitutional Court and the government acting in parliament for the supreme constitutional authority in the country. The events of constitution-making after 2010 seem to contradict the iconic statement in the early jurisprudence offering the foundations of a culture of the rule of law in Hungary that "the rule of law cannot be achieved against the rule of law". ${ }^{44}$

\subsection{The instability of the Fundamental Law}

The constitution-making process which started in 2010 and which led to the adoption of the Fundamental Law and to a series of major modifications to the brand new constitutional text made instability and uncertainty the second nature of the new constitutional order. The technical cause of constitutional instability and uncertainty lies in the relative easiness of pushing a constitutional amendment through the Hungarian parliament, which requires a two-thirds majority vote of all members. ${ }^{45}$ This, however, does not change the fact that the frequent amendments of the Fundamental Law pursued ad hoc political interests represented - likely in bad faith - in the parliament of the day. These could involve considerations, such as reproaching the Constitutional Court through constitutional modifications for unfavourable decisions, preventing in advance the constitutional review of controversial legislation by raising the matter to the constitutional level, or excluding compliance with Constitutional Court judgments by declaring in the constitutional text the unlawful practices in question as constitutional. ${ }^{46}$ The frequent modifications of the Fundamental Law also raise the question whether the stability of

\footnotetext{
43 The state of constitutionalism and the rule of law in Hungary has become since 2011 a subject-matter for constant debate and contestation in the European Union. See the triple-infringement procedures initiated by the Commission against Hungary in 2012 on constitutional matters, http://europa.eu/rapid/press-release_IP-12-24_en.htm?locale=en, and the ensuing judgments, Case C-286/12 Commission v Hungary ECLI:EU:C:2012:687 and Case C-288/12 Commission v Hungary ECLI:EU:C:2014:237. The European Parliament has hosted regular debates on democracy and the rule of law in Hungary. It is evident that the Commission Communication on 'A New EU Framework to Strengthen the Rule of Law' was inspired, in part, by Hungarian developments, http://ec.europa.eu/justice/effectivejustice/files/com_2014_158_en.pdf. The Council Conclusions on 'Ensuring respect for the rule of law' adopted in response are careful not to refer to individual Member States, http://www.consilium.europa.eu/uedocs/cms_Data/docs/pressdata/EN/genaff/146348.pdf.

${ }^{44}$ Supra n. 6.

45 This was also the case with the 1989 Constitution.

${ }^{46}$ See, the reaction to the Court's annulment in Decision 45/2012 of the provision in the Transitional Provisions to the Fundamental Law on the ability of the government to impose extra taxes so as to meet obligations resulting from rulings by the Constitutional Court or by the Court of Justice of the EU of raising this rule to the constitutional level by means of the Fourth Amendment, which was repealed eventually by the Fifth Amendment after the Commission had raised the matter with the government. See also the circumstances of delimiting the review powers of the Court in infra n. 55 .
} 
the constitutional text, which in the Hungarian Rechtsstaat enjoys the position of superior law, should be regarded as a value under the rule of law. ${ }^{47}$

The Fundamental Law adopted has been amended five times since $2011 .^{48}$ These were all major modifications of the constitutional text and the related constitutional practice. ${ }^{49}$ The growing exposure of the constitution to political power through these amendments was followed with keen interest by European bodies which were not afraid to raise criticisms of controversial, politically unsavoury developments. ${ }^{50}$ The Venice Commission of the Council of Europe issued 11 opinions concerning changes in Hungarian public law since 2010, the most relevant of which focused on the adoption and the modifications of the Fundamental Law. ${ }^{51}$ Its opinion on the most controversial Fourth Amendment of the Fundamental Law, the circumstances of the adoption of which are discussed below, emphasised, besides pointing out the substantive shortcomings found in the Hungarian constitutional system, that the frequent amendments of the Fundamental Law reflect an instrumental view of the constitution by the government, which is regarded to be available as a means to be used in politics, and they indicate that the boundary has disappeared between ordinary politics and the political process of constitution-making. ${ }^{52}$ The opinion noted that some of the new constitutional provisions were introduced as reactions to unfavourable decisions by the Constitutional Court aiming to circumvent the limitations imposed on government action by those decisions by raising the issues affected to the constitutional level and, thus, making the criticisms formulated by the Court as irrelevant as a matter of formal legal obligations. It held that such developments undermine the ability of the Constitutional Court to fulfil its main function of controlling 'the democratic system of checks and balances'. This, together with the other provisions of the Fourth Amendment affecting the review powers of the Court ${ }^{53}$ were held to 'amount to a threat for constitutional justice and for the supremacy of the basic principles contained in the Fundamental Law'.

\subsection{Constitutional review under the Fundamental Law}

The anchoring of the rule of law as the core principle of Hungarian constitutionalism which will effectively contribute to the successful completion of the transformation process from socialist

\footnotetext{
${ }^{47}$ There are a number of instruments which are capable of conserving the constitutional text, such as including unchangeable provisions, requiring a referendum to approve certain amendments, or the requirement to obtain the approval of two consecutive parliaments.

${ }^{48}$ The sixth amendment (new, relaxed rules on introducing special legal order in case of a terror threat) is on the political agenda in 2016. For a scholarly analysis of the amendments, see Sonnevend, Jakab and Csink 2015; Vörös 2014; Zeller 2013.

${ }^{49}$ Such as cementing the model of limited constitutional review, breaking the continuity in the jurisprudence of the Constitutional Court under the 1989 Constitution and under the Fundamental Law, imposing restrictions on the exercise of the right to vote and the freedom of expression, and perpetuated practice of overruling the Constitutional Court's decisions by means of constitutional amendments.

${ }^{50}$ See the EU's involvement in supra n. 43.

${ }^{51} \mathrm{http} / / / \mathrm{www}$. venice.coe.int/webforms/documents/?country=17\&year=all. The opinion providing a comprehensive assessment of the new Fundamental Law, while welcoming the Hungarian attempt at constitutional consolidation, formulated substantive criticisms of the new constitutional order, http://www.venice.coe.int/webforms/documents/?pdf=CDL-AD\%282011\%29016-e.

${ }^{52} \mathrm{http}: / /$ www.venice.coe.int/webforms/documents/?pdf=CDL-AD(2013)012-e.

53 The 'repeal' of its jurisprudence under the 1989 Constitution and the confirmation that its review powers are limited in matters affecting public finances.
} 
Hungary to the Hungarian Republic defined in the 1989 Constitution was as much the achievement of the proactive Constitutional Court of the 1990s endowed with extensive competences in constitutional review as of the declarations of the constitutional text. ${ }^{54}$ Under the 1989 Constitution, the Constitutional Court was given by design a central role in safeguarding the new constitutional order, especially vis-à-vis the executive, the powers of which in the Hungarian parliamentary governmental system are de facto united with those of parliament. Its competences in constitutional review available to enforce constitutional principles, including the rule of law, were essential to separate the branches of public powers and to maintain a balance between them by imposing legal constraints on government acting in parliament.

The new Fundamental Law, maintaining the limitations introduced in controversial political circumstances $^{55}$ a few months after the 2010 elections, ${ }^{56}$ departed from this tradition of a powerful constitutional court capable of enforcing the rule of law. ${ }^{57}$ Article 37(4) in the chapter on public finances holds that in ex post norm control and constitutional complaint procedures the Constitutional Court is prevented, with the exception of the grounds provided by the four so called 'protected fundamental rights', ${ }^{58}$ from engaging in the constitutional review of acts concerning public finances as long as public debt exceeds half of the Gross Domestic Product. ${ }^{59}$ Even though this modification, considering the traditionally restrictive interpretation of the jurisdiction available to the Constitutional Court in matters of fiscal policy, can be assessed as having no practical impact on the policy leeway available to government, it offers a sobering reading of Hungarian constitutionalism where constitutional safeguards and the constitutional guarantees enforced within can be suspended on the government's whim with no foreseeable prospect of their reintroduction. ${ }^{60}$ The conditional nature of the suspension, which circumstance may be regarded as being capable of mitigating its overall negative impact, has only very limited value as despite the explicit commitment of the Fundamental Law to debt reduction there is no guarantee that the government will be able, or will be convinced to achieve the stated public debt

\footnotetext{
${ }^{54}$ Sólyom 2015, pp. 7-10.

55 The limitation of the review powers of the Constitutional Court was a political reaction by the government to a preceding decision by the Court annulling an act which imposed as intended by government retroactive tax obligations (Decision 184/2010 of the Constitutional Court). The quasi nationalisation of the entire private limb of the compulsory pension system followed the introduction of the limitation very shortly, the challenges against which were al declared as inadmissible by the Court on the basis of its new jurisdictional rules in Decisions 3291/2012, 3292/2012, 3293/2012, 3294/2012, 3295/2012, 3296/2012 and 3243/2012.

56 Act 2010:CXIX.

${ }^{57}$ Disapproved by the Venice Commission in its comprehensive report on the Fundamental Law, supra n. 49, and on the Fourth Amendment, supra n. 50, and in the opinion on the new act on the Constitutional Court, http://www.venice.coe.int/webforms/documents/?pdf=CDL-AD\%282012\%29009-e.

${ }^{58}$ The violation of procedural rules in the legislative process, as it follows from the legal certainty principle, may also give rise to review by the Constitutional Court.

59 'As long as state debt exceeds half of the Gross Domestic Product, the constitutional Court may, within its competence set out in Article 24(2)b-e), only review the Acts on the State Budget and its implementation, the central tax type, duties, pension and healthcare contributions, customs and the central conditions for local taxes for conformity with the Fundamental Law or annul the preceding Acts due to violation of the right to life and human dignity, the right to the protection of personal data, freedom of thought, conscience and religion, and with the rights related to Hungarian citizenship. The constitutional Court shall have the unrestricted right to annul the related Acts for non-compliance with the Fundamental Law's procedural requirements for the drafting and publication of such legislation.'

${ }^{60}$ Varju 2012, 325.
} 
target. Paradoxically, under Article 37(4) the Constitutional Court is also prevented from enforcing the debt reduction provisions of the Fundamental Law - assuming that parliament had intended that those provisions are genuinely enforceable in law - which are most likely to be affected by legislative measures of fiscal nature. ${ }^{61}$

3.3 Constitutional review, constitutional amendments and the struggle for the ultimate constitutional authority

As mentioned earlier, some of the amendments of the Fundamental Law were motivated by the government's decision to refuse to comply with unfavourable decisions of the Constitutional Court and to prevent it from exercising its review powers by lifting matters to the constitutional level. This in the process leading to the adoption of the Fourth Amendment culminated in an open struggle for the ultimate constitutional authority in Hungary marking the end of constitutionalism under the 1989 Constitution and the beginning of a new constitutional era. The entry into force of the Fundamental Law was prepared by the so called Transitional Provisions in which the government managed to compile a particularly controversial set of provisions. ${ }^{62}$ In the opinion of the Commissioner for Fundamental Rights, the Transitional Provisions severely violated the rule of law, caused considerable uncertainty in the law, and put the unity and operation of the legal system to risk. ${ }^{63}$ As a response to the constitutional review procedure initiated by the Commissioner, parliament adopted the First Amendment to the Fundamental Law which aimed to prevent the scrutiny of the Transitional Provisions by the Constitutional Court by declaring it to form part of the Fundamental Law. The Court faithful, perhaps for the last time, to its ethos created in the 1990s struck down the majority of rules in the Transitional Provisions. ${ }^{64}$

The most contentious issue in the decision was the Court establishing its jurisdiction, despite the subsequently adopted First Amendment, to review the Transitional Provisions. It argued that it is entitled to exercise its review powers to the extent the Transitional Provisions had substituted the Fundamental Law and had, thus, disrupted its coherence and structure. The Court also claimed to have jurisdiction to review the provisions which affected its competences in constitutional review. In addition, it made a vague reference to the possibility that future amendments to the Fundamental Law could be subject to review on the basis of international standards pertaining to the rule of law. ${ }^{65}$ The government reacted by adopting the Fourth Amendment which incorporated into the Fundamental Law most of the provisions which had been found unconstitutional by the Court. In order to cement the superior constitutional authority of

\footnotetext{
${ }^{61}$ As Zoltán Szente assesses, 'the elimination of constitutional review of the public finance legislation (...) creates the impression that the constitutional constraints of the executive power can be put aside in economically difficult times.', Szente 2015, 195.

${ }^{62}$ See Halmai and Scheppele 2012.

${ }^{63}$ Petition of the Ombudsman to the Constitutional Court concerning the Transitional Provisions, $<$ http://www.ajbh.hu/en/web/ajbh-en/press-releases/-/content/14315/26/petition-of-the-ombudsman-to-theconstitutional-court-concerning-the-transitional-provisions-of-the-fundamental-law> (accessed 30 November 2013). ${ }^{64}$ Decision 45/2012. The governing party declared immediately after the decision that the annulled provisions will be inserted into the Fundamental Law by way of a constitutional amendment.

65 The Court in Decision 12/2013 acting in the review of the Fourth Amendment, although it rejected the admissibility of the application, made similar references to international and European constitutional achievements.
} 
government acting in parliament, and to take the edge out of potential future attempts by the Court to oppose government action in the spirit of pre-2010 constitutionalism, the Fourth Amendment repealed every decision of the Constitutional Court which had been delivered prior to the entry into force of the Fundamental Law. ${ }^{66}$ The negative impact of this latter development on ordinary courts and individuals entertaining expectations as to the meaning of constitutional principles seems to have been ignored by government.

\section{Ruled by law, but how? - economic regulation in Hungary after 2010}

The shift from a constitutional culture where the rule of law confined government action to which where the law is used to enable government to rule, which played out at the constitutional level in the controversies surrounding the amendments of the Fundamental Law and the delimitation of the review powers of the Constitutional Court, manifested perhaps most visibly in practices of economic regulation and their constitutional review in the Hungary of the new Fundamental Law. The evidence of this change was brought to light by the diametrically opposite outcomes of the judicial scrutiny of the relevant Hungarian measures before national and European judicial fora. While the Hungarian Constitutional Court deferring uncritically to government political and policy discretion upheld the majority of instruments, the Strasbourg and the Luxembourg courts found violations of core principles connected to the rule of law, such as legal certainty, the right to judicial protection, and the protection of legitimate expectations. While considerations of effective governance can indeed be balanced against the constitutional principles confining government action, it is doubtful that the Hungarian practice of overlooking arbitrary and abusive interferences through legal regulation in the economic private domain with the rights and expectations of market participants is acceptable under the rule of law.

\subsection{Economic regulation in Hungary after 2010}

Aided by a new constitutional framework, the Hungarian government since 2010 has been active in the radical restructuring of numerous, well-identifiable sectors of the national economy. ${ }^{67}$ The legal regulation used in these processes placed an obvious emphasis on policy effectiveness, irrespective of what that policy may be and how it may be achieved, and their preparation and application seemed to have ignored even the most fundamental limitations which may follow from the rule of law. ${ }^{68}$ Supported by vague references to the pressures of the global financial and economic crisis, most sectoral restructurings in the Hungarian economy took place in processes characterised by a low degree of transparency and a high degree of executive discretion, where incumbent economic operators were refused a genuine transitional period to adapt to the new

\footnotetext{
${ }^{66}$ Before the Fourth Amendment, the Court followed the practice of revisiting its previous jurisprudence adopted under the 1989 Constitution in case the text of the constitutional provisions was the same in the two documents, see Decision 22/2012. Decision 12/2013 on the Fourth Amendment established that under strict circumstances the previous jurisprudence may indeed be considered.

${ }^{67}$ Tobacco retail: Acts 2012:CXXIV, 2014:XCV, 2014: XCIV; food retail: Acts 2014:LXXIV, 2014:CXII, 2012:CLVII; advertising and media: Act 2014:LXXIV; gambling (slot machines): Acts 2011: CXXV, 2012: CXLIV, 2013: CXXVI and CLXXXV; the tax-free remuneration vouchers market: Act 2011: CLV and Government Regulation 55/2011; the private-pensions market: Acts 2010: C and CI, 2011:CXCIV, Act 2010:CLIV.

${ }^{68}$ For an analysis of the balance found between policy effectiveness and constitutional protection in these measures, see Varju and Chronowski 2015.
} 
legal circumstances, and where fiscal measures were introduced to disfavour incumbents either by driving them out of markets or by securing competitive advantages to their local competitors. The extremely narrow timeframes for introducing changes also ensured that government policy is executed before legal challenges can be mounted against them. The selection of market participants allowed to remain in, or to enter the markets - predominantly through licensing took place with the interests of local economic operators, or of the State in mind. While a thin veil of formal legality was always kept, law seems to have been used to coerce - mostly foreign owned - market participants to reconsider their market position, or to leave the market, and the application of the measures were often at odds with the legal limitations which follow from the rule of law on the use of public powers.

There are, however, a number of factors which need to be taken into account to provide a more balanced assessment of government interventions in the national economy. First of all, the above practices characterise only certain sectors of the national economy. Current Hungarian economic policy, following the aims of fostering competitiveness and growth, favours export-oriented producing sectors, and the sectors focusing on the national market, mainly in the services industry, are made to suffer the interventions of the revenue- and reform-hungry government. Secondly, some of these changes were introduced as a result of the government trying to experiment with policy and regulation to offer solutions in extremely hard financial and economic circumstances. The experimental introduction of new indirect taxes formed part of a tax policy which pursuing the objectives of increasing growth and employment aimed to increase the relevance of indirect taxes within the domestic tax structure. The progressive nature of these taxes, which may be regarded as a somewhat unconventional policy tool, was based on the idea of maximising tax revenue for the state budget. Finally, government interventions in the economy declaredly pursued robust objectives in the general interest which in a state on the economic and social fringe of Europe seemed not only justifiable but also popular with the electorate.

\subsection{The Constitutional Court's near total deference}

The undemanding assessment of the Constitutional Court of these developments in economic regulation suggests a limited role for the rule of law under the Fundamental Law. ${ }^{69}$ Its decisions deferred liberally to executive discretion, and following vague, and often confused references to the global financial and economic crisis and to the demise of global capitalism, refused to test government economic policy action even on the most basic requirements which may follow from the rule of law. ${ }^{70}$ The basic standards of regulatory design and quality, which had been recognised under rule of law principle of the 1989 Constitution and which had been more or less

\footnotetext{
${ }^{69}$ On how these decisions shaped economic constitutionalism under the new Fundamental Law, see Varju and Chronowski 2015. The protection of acquired rights and of legitimate expectations seems have disappeared completely, see Decisions 23/2013 and 26/2013 of the Constitutional Court. In general, in the new constitutional complaint procedures, which now take up the majority of the time of the Court, only the most visible violations of the rule of law are investigated, such as the prohibition of adverse retroactive effect, Order 1140/D/2006 of the Constitutional Court.

${ }^{70}$ Decisions 3062/2012, IV/03567/2012, 3194/2014 and 20/2014 of the Constitutional Court.
} 
consistently enforced by the Constitutional Court, ${ }^{71}$ were ignored. In the District Heat Market Price Regulation decision, ${ }^{72}$ which addressed controversial government pricing policy in the public utilities sector preparing the departure of market participants from that sector and the establishment of a new state monopoly, the Court having summarily dealt with what it conceived as the global context of local price regulation rejected to engage in the slightest scrutiny of the local legal and policy environment. The decision was carefully tailored to answer the question which supported government policy and to avoid questions which would have raised doubts as to the legitimacy of government intervention. While it established that entry into the market was not restricted by the measure, it kept silent about the more evident consequence of price regulation of expelling economic operators from the market. It was not discussed whether the latter is a justifiable objective of government policy and whether it is a consequence which was achieved in accordance with the rule of law.

In its Slot Machines decision dealing with government restructuring of the gambling market, ${ }^{73}$ the Court found no error in the legislation which banned with immediate effect the operation of slot machines in leisure arcades. Feeling constrained by the policy discretion enjoyed by government in this market, it refused to scrutinise the potential hiatuses of government intervention. As opposed to the Court of Justice of the EU, it was not troubled by the policy inconsistency affecting the area which favoured certain but disfavoured most other economic operators, and it did not find it necessary to discuss the legal circumstances, namely the lack of a transitional period and the unavailability of compensation for the individuals affected, in which the near complete closure of a market took place. The Sale of Tobacco Products decision ${ }^{74}$ applied the manifest unreasonableness test in the scrutiny of the massive overhaul of the Hungarian tobacco retail market. This meant that the Court could overlook the impact of government policy on the rights and expectations of the incumbent economic operators, and that it could ignore the legal hiatuses of the new licensing regime. The impoverished scrutiny of the Court found a further expression in the economically highly significant Cooperative Banking Restructuring decision, ${ }^{75}$ where instead of examining whether the impugned legislation is compliant with the rule of law, the Court attempted to justify, on the basis of a rather disturbing understanding of the political economy of the state and of regional and global markets, its total surrender to government policy.

The Foreign Currency Consumer Loan decision ${ }^{76}$ of the Court, which does not fall within the line of cases aiming to exonerate government restructurings of markets, provides perhaps the most disturbing reading of the rule of law in contemporary Hungarian constitutionalism. Predisposed to continue with its newly established deferential approach to government policy, the Court dismissed the claims relating to the principle of legal certainty, the prohibition of

\footnotetext{
${ }^{71}$ Supra nos. 32-37. From the pre-Fundamental Law jurisprudence, see, especially, Decisions 32/1991, 35/1991, 21/2001, 11/1992, 26/1992, 28/1992 and 8/2003 of the Constitutional Court.

${ }^{72}$ Decision 3062/2012 of the Constitutional Court.

${ }^{73}$ Decision IV/03567/2012 of the Constitutional Court.

${ }^{74}$ Decision 3194/2014 of the Constitutional Court.

${ }^{75}$ Decision 20/2014 of the Constitutional Court.

${ }^{76}$ Decision 34/2014 Constitutional Court. See also Decision 2/2015 of the Constitutional Court which confirmed the grounds decided in Decision 34/2014.
} 
retrospective legislation and the right to a fair trial. The central, deeply troubling conceptual frame of the decision was that even though the judgment of the EU Court of Justice in Kásler ${ }^{77}$ and the corresponding 2/2014 uniformity decision by the Curia were instrumental to clarifying the meaning of the relevant provision of Hungarian law and to giving directions to a confused judicial practice, this circumstance does not entail that Hungarian law was supplemented by a hitherto unknown legal rule. While formally this assessment seems to be correct as the relevant EU directive had been implemented way before the legal disputes in questions appeared, it is faulty in the respect that it assumes that market participants, and their consumers, should have accorded the meaning discovered only in 2014 to the given provision of Hungarian law from the day foreign currency consumer contracts appeared in the Hungarian market. The fact that the legislation under scrutiny offered the first explicit expression by government in law that foreign currency consumer loan contracts may be illegal was not considered as relevant.

Building on this rather harsh interpretation of legal certainty, the Court first refused the claim that economic operators had not been given sufficient time to adapt to the new legal environment. While it accepted that the time between the adoption and the entry into force of the new legislation was 'unusually short', the Court found it suitable to argue that previous judicial practice and other pieces of legislation had already indicated what the content of the new legislation adopted by government will be. It also added, albeit without giving explanations, that the new act did not require lengthy preparations from individuals. Even more controversially, the Court, again ignoring that the interpretation of the law was only clarified in Kásler, held that the vulnerable position of consumers and the information deficit favouring financial institutions themselves should have been sufficient for the economic operators concerned, despite the inability of consecutive governments to take a clear view on this matter, to come to the conclusion even before the adoption of the legislation under scrutiny that they violated the requirement of contractual fairness laid down in general terms in Hungarian law.

This reasoning, which placed the burden of interpreting correctly a highly uncertain provision of law solely on economic operators, was continued in the scrutiny of the claim concerning fair trial rights. Firstly, the Court readily accepted that the contentious procedural arrangements of the legislation in question were justified by the interest of the effective administration of justice. Secondly, it was prepared to rule that the original bill laid and discussed before Parliament was sufficient to enable the economic operators affected to prepare their case in the special judicial actions put into operation by the act. It held, in particular, that the economic operators concerned had 'every reason to believe' - on the basis of the media reports on the government's intention to intervene in this matter - that legislation will eventually be adopted to regulate the special judicial procedures in question. Finally, the Court decided to shift all remaining responsibility for the controversial procedural arrangements onto the economic operators affected which, according to the Court, must be assumed to have adequate professional legal and financial resources to prepare their cases irrespective of whether the timeframe made available to them affected their position adversely.

\subsection{The exacting scrutiny of the Court of Human Rights}

\footnotetext{
${ }^{77}$ Case C-26/13 Kásler ECLI:EU:C:2014:282.
} 
In contrast with the Constitutional Court's disengaged review of Hungarian economic regulation, which was prepared to overlook what can be regarded as blatant violations of basic standards of legal certainty, the European judicial fora drawn into the scrutiny of these measures, by asking the questions and raising the concerns omitted by the Hungarian Court, gave a condemning assessment of government interventions in the market. The scrutiny of the restructuring of the tobacco retail market by the European Court of Human Rights in Vékony was what perhaps had been expected from the Constitutional Court. Proceeding under Article 1 Protocol 1 ECHR on the right to property, the Strasbourg Court focused not solely on the extent of policy discretion available to government, but also on the impact of the measure on individuals. In this regard, it emphasised that the serious economic consequences of the Hungarian act affected the applicant severely, ${ }^{78}$ and that changes were put into effect within an extremely narrow timeframe offering an insufficient transitional period to make the necessary adjustments. ${ }^{79}$ The ruling also brought attention to matters of quality and design in regulation and in governance. It held that licencing procedures must be transparent, they must be devoid of arbitrariness, discrimination, or disproportionate harshness, and that they must entail safeguards against arbitrary decisions and must provide a reasonable opportunity for the effective judicial challenge of the decision taken. ${ }^{80}$ Regarding specifically the Hungarian measure, the Strasbourg court found that there was no compensation, or other positive measure capable of alleviating the negative consequences of government interference offered to individuals, there was no judicial redress available to the person concerned, and that individuals were not provided adequate possibilities 'to respond to the impending change to their source of livelihood'. ${ }^{81}$ The ultimate assessment of the judgment was that the restructuring of the market 'was verging on arbitrariness' and it lacked sufficient transparency. ${ }^{82}$

\subsection{Failing the EU's test}

Before the Court of Justice of the EU, rather similar hiatuses of Hungarian economic regulation were pointed out. The recent ruling by the Luxembourg Court in the infringement case brought against Hungary ${ }^{83}$ concerning the restructuring of the tax-free remuneration vouchers market gave an extremely critical account of Hungarian practices in economic regulation. Unfortunately, having established the blatant violation of core provisions of EU law, ${ }^{84}$ the Grand Chamber decided not to analyse the legal circumstances in which the Hungarian government handed over

\footnotetext{
${ }^{78}$ para. 33, Vékony v Hungary, Judgment of 13 January 2015, App. no. 65681/13, nyr.

${ }^{79}$ para. 34 , ibid.

80 ibid.

${ }^{81}$ Para. 35, ibid. It also emphasised that 'the measure was introduced by way of constant changes of the law and with remarkable hastiness, the loss of the old licence was automatic, and the non-acquisition of a new one was not subject to any public scrutiny or legal remedy.'

${ }^{82}$ Para. 36, ibid.

${ }^{83}$ Case C-179/14 Commission v Hungary ECLI:EU:C:2016:108.

${ }^{84}$ The way the court established the violation of EU law does include an indirect assessment of the legal circumstances of regulatory intervention: the risk of violating EU obligations must have been known, the provisions were clearly discriminatory, and the case involved clear regulatory favouritism to the advantage of local undertakings and to the disadvantage of their foreign competitors.
} 
an entire market to a state monopoly. ${ }^{85}$ Nonetheless, it is clear from the judgment that the Hungarian government was either unable to state with reference to evidence the rationales of its intervention in the market, ${ }^{86}$ or its explanations as to the objectives pursued were found irrelevant in the circumstances of the context of market regulation. ${ }^{87}$ The failure of Hungary's case suggests that the government did not feel constrained by the Fundamental Law to adopt legislation for the sole purpose of replacing the incumbent economic operators of a lucrative market with a revenue-producing state monopoly and with a group of favoured Hungarian economic operators.

In Berlington, which concerned the enclosure by legislation of the Hungarian gambling market, the EU Court of Justice, having accepted that in this economic domain the Hungarian legislator enjoys a considerably broad margin of policy discretion, ${ }^{88}$ found that the legal measures violated the principles of legal certainty and of the protection of legitimate expectations. ${ }^{89}$ This was achieved with an explicit reference to the principle followed in the earlier analysed Strasbourg ruling on the restructuring by Hungary of the tobacco retail market. ${ }^{90}$ It held that a sufficient transitional period enabling individuals to adapt to the new circumstances, or reasonable compensation system should have been offered in a market where economic operators had made costly investments to comply with the regulatory framework replaced by the impugned measure. The sudden and unforeseeable nature of the changes was especially condemned by the EU Court.

Other measures of economic regulation are now under investigation by the European Commission in infringement procedures or under EU state aid law for the violation of EU law. ${ }^{91}$ The progressive fiscal measures introduced in most markets affected by government restructuring raise an interesting dilemma not only under EU law, but also under Hungarian constitutional law. While, in case they do not bring about direct or indirect discrimination, the progressive nature of these direct taxes, although it is unconventional, cannot be criticized on formal legal grounds, ${ }^{92}$ the Hungarian government seems to have taken extra care so that they involve progressive elements which favour certain economic operators and disfavor their predominantly foreign owned competitors. The Commission is investigating these discriminatory elements of Hungarian tax law on the basis that they constitute a selective economic advantage prohibited by state aid law. ${ }^{93}$

\section{Conclusions}

\footnotetext{
${ }^{85}$ Para. 174, C-179/14 Commission v Hungary, supra n. 83, in particular, the failure to grant a genuine transitional period, and the use of tax legislation to force incumbent economic operators out of the market.

${ }^{86}$ Paras. 69, 92-94, 115-116,171-173, ibid, in particular, the interest of sufficient integration into the local economy, the availability of sufficient experience and infrastructure, and the availability of sufficient guarantees to consumers and creditors.

${ }^{87}$ Paras. 167-170, ibid. The rejection of the social policy grounds, as laid down in Act 2012:CIII, was the most painful to the government which seemed convinced that the measure had been adopted within social policy competences.

${ }^{88}$ Para. 56, Case C-98/14 Berlington EU:C:2015:386.

${ }^{89}$ Paras. 74-91, ibid, especially, paras. 85 and 87.

${ }^{90}$ Supra n. 77.

${ }^{91}$ IP-15-5375 and IP-15-4598.

92 Paras. 37-41, Case C-385/12 Hervis EU:C:2014:47.

${ }^{93}$ Decisions SA.41187, SA.39235 and SA.40018.
} 
This article aimed to establish that in the constitutional order created for Hungary after 2010, because of its exposure to politics, the legacy of a strong rule of law principle developed by the strong Constitutional Court in the 1990s has been replaced with an instrumental understanding of the law as a means available to rule. Not only the review powers of the Constitutional Court, which had traditionally been deemed essential to uphold the rule of law, but also the constitutional text itself fell victim of this new, vacated understanding of the law and the constitution in Hungary. In the area of economic regulation, it is clearly visible how this development has put in law the rights and expectations of individuals to jeopardy and how it enables the government acting in parliament to enforce without meaningful controls its will. Without the intervention of European bodies, the Fundamental Law's explicit commitment to uphold the rule of law would have become an empty declaration.

\section{Reference list}

Chronowski, N, Drinóczi, T and Petrétei, J (2011) The Governmental System of Hungary. In: Chronowski, N, Drinóczi, T and Takács, T (eds), Governmental Systems of Central and Eastern European States. Wolters Kluwer Polska, Warszawa, pp. 299-366

Halmai, G, Scheppele, KL (2012) Amicus Brief for the Venice Commission on the Transitional Provisions of the Fundamental Law and the Key Cardinal Laws. http://halmaigabor.hu/dok/426_Amicus_Cardinal_Laws_final.pdf. Accessed 30 November 2013

Győrfi, T, Jakab, A (2009) Jogállamiság. In: Jakab, A (ed), Az Alkotmány kommentárja.

Századvég, Budapest, pp. 155-210

Petrétei, J (2009) Az alkotmányos demokrácia alapintézményei. Dialóg Campus, Budapest-Pécs.

Sonnevend, P, Jakab, A, and Csink, L (2015) The Constitution as an Instrument of Everyday Party Politics: The Basic Law of Hungary. In: von Bogdandy, A and Sonnevend, P (eds), Constitutional Crisis in the European Constitutional Area. Hart Publishing, Oxford, pp. 33-110

Sólyom, L (2000) Introduction to the Decisions of the Constitutional Court of the Republic of Hungary. In: Sólyom, L and Brunner, G (eds), Constitutional Judiciary in a New Democracy. The Hungarian Constitutional Court. University of Michigan Press, Ann Arbor, pp. 1-64

Sólyom, L (2015) The Rise and Decline of Constitutional Culture in Hungary. In: von Bogdandy, A and Sonnevend, P (eds), Constitutional Crisis in the European Constitutional Area. Hart Publishing, Oxford, pp. 5-32

Szente, Z (2015) The Decline of Constitutional Review in Hungary - Towards a Partisan Constitutional Court?. In: Szente, Z, Mandák, F, Fejes, Zs (eds), Challenges and Pitfalls in the Recent Hungarian Constitutional Development. L'Harmattan, Budapest, pp. 185-219

Tóth, GA (2009) Túl a szövegen. Értekezés a magyar alkotmányról. Osiris, Budapest

Varju, M (2012) Governance, Accountability and the Market. In: Tóth, GA (ed), Constitution for a Disunited Nation. Central European University Press, Budapest, New York, pp. 301-331 
Varju, M and Chronowski, N (2015) Constitutional backsliding in Hungary. TvCR 6:296-310

Vörös, I (2014) The constitutional landscape after the fourth and fifth amendments of Hungarian Fundamental Law. Acta Juridica Hungarica 1-20

Zeller, J. (2013) Nichts ist so beständig... Die jüngsten Novellen des Grundgesetzes Ungarns im Kontext der Entscheidungen des Verfassungsgerichts. Osteuropa-Recht 307-325 